\title{
DISTANCE LEARNING AS A DIRECTION OF REFORMING PUBLIC ADMINISTRATION IN THE FIELD OF HIGHER EDUCATION
}

\author{
Bilous-Osin T. I., Kozachuk D. A.
}

\section{INTRODUCTION}

The threat of the spread of coronavirus infection in 2019 (hereinafter COVID-19) mediated the introduction of significant changes in the usual state and dynamics of social relations. In Ukraine, it can be noticed a process of finding consensus between forced restrictive measures that have changed the instrumental expression of public administration in all spheres of public relations and the preservation of values, which are aimed at public administration in general. Under such conditions, the instruments of public administration also in the field of higher education during the implementation of quarantine are characterized by casuistic tendencies of inconsistency of the existing situation with the model of proper public administration, which they are trying to implement. First of all, this concerns the lack of normative and institutional support for distance learning, which has become the main way to receive education in the context of combating the spread of the COVID pandemic- 19 . The importance of changes in public administration in higher education is confirmed by Council of Europe recommendations ${ }^{1}$.

A negative feature of public administration in the field of higher education in the fight against the spread of the COVID-19 pandemic is, first of all, an unsuccessful attempt to reformat the state management system into a public administration system, as the latter is characterized by prompt resolution of gaps and flaw in legal regulation. Any significant changes to the way of organizing power-administrative influence on public relations in the field of higher education can not be formed in isolation from the real problems of their perception and provision. It seems necessary to develop both a long-term concept of sustainable development of the system of managerial influence in the quarantine regime, and simultaneous monitoring of existing and emerging problems in the field of higher education. At the same time,

\footnotetext{
1 Дотримання демократії, верховенства права та прав людини під час санітарної кризи, спричиненої COVID-19. Інформаційні документи. Рада Свропи. 7 April 2020 SG/Inf(2020)11. URL: https://www.coe.int/en/web/congress/covid-19-toolkits.
} 
an integral element of such a system is distance learning as a universal, synthetic, integrated, humanistic form of learning that creates the necessary conditions for students and is adapted to the basic level of knowledge and specific goals of the learner.

It is necessary to proceed from the fact that the introduction of distance learning in the field of higher education and the development of regulatory and institutional mechanisms for its functioning has been discussed for a long time. Thus, the modern information society is characterized by the widespread use of information and communication technologies, including distance learning technologies as a means of improving the efficiency of professional and educational activities. Of particular importance in the information society of mass global communication is the informatization of education, which is seen as a purposefully organized process of providing education with methodology, technology and practice of creating and optimal use of scientific and pedagogical, educational, program-technological developments technologies. However, at present, the introduction of distance learning in higher education is an unalterable step to preserve it in general.

Thus, the relevance of the research topic is beyond doubt and is determined by the need to consider both the basic principles of using distance learning services and electronic educational resources that meet the requirements for their pedagogical and ergonomic quality, and regulatory and institutional principles of distance learning as remote information interaction combating the spread of the COVID-19 pandemic.

\section{The fundamental principles of the use of distance learning in higher education}

For the first time, the formal use of the term «distance education» is associated with the change of name of the International Council for Correspondence Education to the International Council for Distance Education in $1982^{2}$. Based on the experience of distance learning, by the National Centre for Education Statistics of the United States of America (hereinafter - the USA) four generations of distance learning tools have been identified depending on the main criteria that differentiate the characteristics of each generation: 1) the number of individuals who can simultaneously interact with each other (unilateral, bilateral or the relationship of many

${ }^{2}$ Корсунська Н.О. Дистанційне навчання: підходи до реалізації. Сучасні інформаційні технології та інноваційні методики навчання в підготовці фахівців: методологія, теорія, досвід, проблеми: Зб. наук. праць. Київ-Вінниця: ДОВ Вінниця, 2000. С. 29-32. 
users); 2) the amount and type of information (voice, video data) that can be transmitted; 3 ) information transfer rate.

A single interpretation of the concept of the category «distance learning» has not been developed to date. Distance learning in the field of higher education can be considered as: 1) a way of learning process; 2) pedagogical technology; 3) the method of managerial influence in the field of education; 4) form of education.

Distance learning as a way of learning process means its organization, in which the teacher develops a curriculum, which is mainly based on selfstudy by the student. This educational environment is characterized by the fact that the higher education recipient is separated from the teacher in space and / or time. At the same time, the higher education recipient and the teacher have the opportunity to engage in dialogue through telecommunications ${ }^{3}$.

Distance learning as a pedagogical technology differs from traditional full-time and part-time ${ }^{4}$,as it is determined not only by the expansion of the range of media and means of access to them, but also the presence of constant communication between teacher and graduate through telecommunications channels. Thus, the impact of distance on the educational process concerns the information and educational system of remote access, based on modern information technologies.

The definition of distance learning as a way of managerial influence in the field of education is mediated by the interpretation of this concept as an activity for the purposeful methodological guidance of educational and cognitive activities and development of persons who are at a distance from the educational institution and do not come into constant contact with its scientific and pedagogical staff 5 .

As for the definition of distance learning as a form of learning, it is advisable to interpret it as a universal, synthetic, integrated, humanistic form of learning, which creates the conditions for distance learning ${ }^{6}$. A similar interpretation is based on Ukrainian experts in creating the Ukrainian Centre for Distance Education, which states that the distance form of education can be understood as a form that uses

\footnotetext{
${ }^{3}$ Кашицин В.П. Дистанционное обучение в высшей школе: модели и технологии. 3-е изд. доп. М.: Центр информатизации Минобразования России, 2009. 42 с.

${ }^{4}$ Kose U., Koc D. Artificial Intelligence Applications in Distance Education. - IGI Global, 2014. 357p.

${ }^{5}$ Negash S., Whitman Michael E., Woszczynski Amy B.. Handbook of Distance Learning for Real-Time and Asynchronous Information Technology Education. - New York: Hershey, 2008. 381 p.

${ }^{6}$ Боцула М.П., Кречман Д.Л., Плахотник I.B. ELearning Server. Рекомендації тьюторам. Методичний посібник. 2-е вид. Вінниця: ВНТУ, 2015. 158 с
} 
global computer communications such as the Internet and is based on individual work of higher education with appropriately structured education-methodical support ${ }^{7}$.

Conceptually, distance learning involves the receipt of educational services at a distance using computer and communication technologies through targeted and controlled independent activities of the recipient, who can study in a convenient place, on an individual schedule, using a set of special distance learning tools and agreed opportunity interaction with the teacher. It is considered expedient to use a comprehensive approach to the definition of distance learning in higher education, in which each of its content and quality characteristics will be taken into account.

The specifics of distance learning in the field of higher education in comparison with its traditional forms consists in the following features:

1) the flexibility of distance learning, which is ensured by: a) the absence of a requirement of higher education students to attend regular classes in the form of lectures and practical classes; b) created learning opportunities at a time convenient for recipients of higher education, in their chosen place and within the limits necessary for the development of educational material;

2) parallelism of distance learning programs, which provides an opportunity to combine the main professional activity with training «without discontinuing work»;

3) «action at a distance» of distance learning, which determines the optional short distance in the provision of educational services and eliminates the distance between the student's location and the educational institution as an obstacle to an effective educational process;

4) wide coverage of distance learning, which provides the opportunity for simultaneous training of a large number of higher education recipients who are given access to sources of educational information (electronic libraries, databases), as well as the choice of communication with other participants in the educational process;

5) profitability of distance learning, which is achieved through the effective use of existing infrastructural resources and technical means of information technology, as well as the presentation of concentrated and unified content of educational materials;

6) reassessment of the status of a teacher («tutor»), which involves assigning him the functions of coordinating the cognitive process, adjusting the course of the discipline, counseling, management of educational

${ }^{7}$ Биков В.Ю., Кухаренко В.М. Технологія розробки дистанційного курсу. Київ: Міленіум, 2008. $324 \mathrm{c}$. 
projects, etc. In this case, the teacher's interaction with higher education students can be carried out asynchronously via e-mail, software designed for the user of gadgets, and synchronously («chat talk»);

7) reassessment of the status of the recipient of higher education, within which he is required to have exceptional motivation, self-organization, diligence and the necessary basic level of education, etc ${ }^{8}$.

Hence, the process of distance learning (didactic system) is the transfer of information of a certain content (knowledge, skills, abilities), the ultimate goal of which is the ability of the recipient of higher education to use this information in their activities. The main characteristics of the process of information transfer within distance learning are: 1) the main cognitive process through which the process of transmission, assimilation and application of information by the recipient; 2) the level and nature of feedback from the recipient of higher education in the learning process, as well as the degree of adaptation of the learning process to the individual characteristics of the recipient of higher education, which are, for example, psychological personality structure, sociological personality structure, level of learning and learning ability; management style of the learning process, which is based on the principled recognition or non-recognition of the fact of individuality of the student's personality and can be authoritarian or humanistic.

Regarding the separation of positive and negative trends related to the introduction of distance learning in higher education, they relate to the following indicators of the quality of education. The positive dynamics of the development of higher education through distance learning is manifested in: the independence of the possibility of obtaining higher education from the geographical location and from socio-economic factors ${ }^{9}$; reduction of material and time costs for training; efficiency of providing participants of the educational process with educational and methodical materials ${ }^{10}$; the possibility of mastering by higher education students of individual educational programs with methodical support of training by highly qualified pedagogical workers due to the implementation of remote information interaction of educational purpose and the use of educational

\footnotetext{
${ }^{8}$ Концепція розвитку дистанційної освіти в Україні: Постанова Міністерства освіти та науки України від 20 грудня 2000 р. Міністерства освіти та науки України від 20 грудня 2000 р. URL: http://www.osvita.org.ua/distance/pravo/00.html.

${ }^{9}$ Корсунська Н.О. Дистанційне навчання: підходи до реалізації. Сучасні інформаційні технології та інноваційні методики навчання в підготовиі фахівців: методологія, теорія, досвід, проблеми: Зб. наук. праць. Київ-Вінниця: ДОВ Вінниця, 2000. С. $29-32$.

${ }^{10}$ Гусак Т., Малінко О. Можливості та перспективи дистанційного навчання у вузі. Рідна школа. 2000. № 10. С. 41-42.
} 
materials presented in electronic form ${ }^{11}$. It is necessary to dwell on the absence of significant changes in the motivation of recipients of higher education depending on the traditional and distance approach to learning, as proved in a study conducted by Kivalov S.V. and Bila-Tiunova L.R ${ }^{12}$.

At the same time, the implementation of distance learning has a number of disadvantages, which include: irregular use of automation in managing the learning process; chaotic information interaction between teachers, recipients of higher education and interactive educational resources ${ }^{13}$; inadequacy of ways of presenting educational materials to the possibilities of modern information and telecommunication technologies ${ }^{14}$. At the same time, proper information technology support of distance learning in higher education should be provided by a set of electronic teaching materials, such as electronic educational resources, electronic educational publications, electronic teaching aids, illustrated hypertext and multimedia textbooks, interactive workshops, test systems, electronic dictionaries and encyclopedias that will be used in teaching and organizing the learning process ${ }^{15}$. However, the analysis of electronic databases for distance learning in the field of higher education in recent years shows their inconsistency with the pedagogical and ergonomic requirements for the use of distance technology in the educational process ${ }^{16}$.

Distance learning in different countries varies depending on the degree of development, institutional security, socio-cultural perception, the level of legal awareness of citizens and the like. For example, a distinctive feature of the distance learning system in the United States is that it is developed not only within educational institutions, but also by individual commercial companies (such as Motorola, Disney, Ford, General Motors, etc.) with a predominant focus on training in in the field of business through staff training; in Europe, distance learning is provided by academic

${ }^{11}$ Кухаренко В.М. Дистанційне навчання. Харків: ХДПУ, 1999. 216 с.

${ }_{12}$ Sergey Kivalov, Liubov Bila-Tiunova (2020) Motivational values of Ukrainian students and the use of distance learning form in legal education. Universal journal of educational research. Vol. 8. No 2. P. 260-283.

${ }_{13}$ Молчина Л.И., Сидорик В.В., Стрелкова И.Б. Технология разработки электронных учебно-методических комплексов / Под общ. ред. В.В. Сидорика, Л.И. Молчиной. Минск: БНТУ, 2015. $263 \mathrm{c.}$

14 Годжаев Р.С. Применение современных технологий в образовательном процессе. Краснодар: Місль, 2012. 196 с.

${ }_{15}$ Шамахов В.А., Суслов Ю.Е., Золотухин В.А. Современное дистанционное образование государственных служащих: проблемы и решения. Санкт-Петербург: Астерион, 2013. 184 с.

16 Демкин В.П., Можаева Г.В. Технологии дистанционного обучения. Монография. Томск: Изд-во Том. ун-та, 2013. 106 с. 
courses, taking into account the needs of the market and strengthening the responsibility of the recipient for the quality of knowledge, the ability to choose disciplines without declaring the ultimate goal of their study ${ }^{17}$. It is noteworthy that distance education in Europe was intensively developed in the early 70's, due to the creation of a number of open universities universities of distance education. Currently, in every European country there is a group of educational institutions that implement distance learning programs. The methods of such training are quite well developed and involve the use of new information technologies, including satellite television, computer networks, multimedia, etc. An illustrative example in this regard is the Universidad National de Educacion a Distancia-UNED in Spain, which includes 58 training centres in the country and 9 abroad (Bonn, Brussels, Geneva, London, Paris, New York, Rome and etc.) ${ }^{18}$.

Along with programs designed for a mass audience, targeted series of lectures and classes have become widespread. One of the examples of the implementation of this area of distance education is the television courses of the Baltic University. Created in Sweden, it unites more than 150 universities in the Baltic region (meaning the area bounded by the Baltic Sea catchment area). The Baltic University program is funded by Swedish government funds, the Swedish Institute, and the participating universities. Using satellite television systems, higher education recipients and scientists have the opportunity to make scientific and educational contacts on topics of common interest, such as the environmental problems of the Baltic region or the development of the peoples of the Baltic region ${ }^{19}$.

Consequently, in European countries open universities dominate in the field of distance learning, there are pronounced integration processes with mutual accreditation of higher education institutions and high quality educational standards. Unfortunately, only some higher education institutions in Ukraine already have or are only developing separate courses, methodological support and electronic textbooks that can be used in distance learning. At the same time, the actions of development agencies were often not coordinated with each other, which led to duplication and irrational use of financial, organizational and professional capabilities of these organizations.

${ }^{17}$ Wilson Greg. Teaching tech together, 2018. 299 p.

18 Patricia L. Rogers, Gary A. Berg, Judith V. Boettecher, Caroline Howard, Lorraine Justice, Karen Schenk, Encyclopedia of Distance Learning, Second Edition (4-Volumes). Information Science Reference, 2009. 2612 p.

${ }_{19}$ Wilson Greg. Teaching tech together, 2018. 299 p. 
To confirm this conclusion, experts dealing with the development of distance learning, note that it is necessary to develop pedagogical aspects of distance education: the transition from a limited concept of physical movement of students from country to country to the concept of mobile ideas, knowledge and learning to share knowledge through the exchange of educational resources between countries; ensuring the long-term goal of distance education development - providing an opportunity for everyone to study the program of any college or university anywhere.

\section{Normative and legal support of distance learning in the field of higher education}

In Ukraine, the right to education is provided by Art. 53 of the Constitution of Ukraine and is expressed through such powers as: the right to unimpeded access to education, the right to free education and the right to receive education in the language of national minorities if necessary ${ }^{20}$. The right to education applies to any level of education, form and type, including vocational (professional and technical), professional higher, higher education and adult education ${ }^{21}$. The right to education is ensured by state funding of relevant socio-economic, educational and scientific programs, creating conditions for effective and affordable educational services. In order to fulfil its tasks, the state, represented by the authorized bodies, must take all necessary measures, including ensuring access to higher education in all conditions, including the functioning of public relations in the field of education under quarantine.

The danger in the form of the COVID-19 pandemic made significant adjustments to the legal framework for all citizens' rights, and the right to higher education for Ukrainian citizens was no exception. In general, higher education is a set of systematized knowledge, abilities and practical skills, ways of thinking, professional, ideological and civic qualities, moral and ethical values, other competencies acquired in a higher education institution (scientific institution) in the relevant field of knowledge at a certain level of higher education, which in terms of complexity are higher than the level of complete general secondary education ${ }^{22}$. The consequences of the

\footnotetext{
${ }^{20}$ Конституція України. Із змінами, внесеними Законом України від 08.12.2004 p. № 2222-IV. Дата оновлення 01.01.2020 p. URL: http://zakon2.rada.gov.ua /laws/show/254\%D0\%BA/96$\% \mathrm{D} 0 \% \mathrm{~B} 2 \% \mathrm{D} 1 \% 80$.

${ }^{21}$ Про освіту: Закон України від 05.09.2017 № 2145-VIII. Дата оновлення: 24.06.2020 p. URL: https://zakon.rada.gov.ua/laws/show/2145-19\#Text.

22 Про вищу освіту: Закон України від 01.07.2014 p. № 1556-VII. Дата оновлення: 21.06.2020 p. URL: https://zakon.rada.gov.ua/laws/show/1556-18\#Text
} 
introduction of restrictive measures in the field of higher education have not yet been studied, but it is obvious that the content of the educational process has changed radically.

The legal quarantine regime determined the application of a set of compulsory preventive, anti-epidemic and other administrative measures, the imposition of temporary restrictions on the rights of individuals and legal entities and additional responsibilities ${ }^{23}$. As things stand at the moment, the introduction of quarantine is marked by the adoption of the relevant decision by the Cabinet of Ministers of Ukraine of March 11, 2020 24 . The administrative measures taken to prevent the spread of the COVID-19 pandemic include a ban on visiting educational institutions by its recipients. In this situation, the way to ensure the right to higher education was to use distance learning instead of full-time and part-time education.

During the counteraction to the spread of the COVID-19 pandemic, some problems related to the organization of higher education were solved by the Ministry of Education and Science of Ukraine. Thus, according the order «On organizational measures to prevent the spread of coronavirus COVID - 19» the heads of educational institutions are obliged to: to ensure the implementation of educational programs by organizing the educational process using distance learning technologies, which does not involve visits to educational institutions by its recipients, and in exceptional cases by consolidating the schedule of the educational process; to ensure the possibility for employees of educational institutions to perform work (organizational and pedagogical, methodological, scientific, etc.) through the introduction of a flexible (remote) mode of operation ${ }^{25}$. In addition, the Ministry of Education and Science of Ukraine has developed recommendations for the organization of current, semester control and certification of applicants for higher education using distance technology. Accordingly, remote communication of participants in the educational process became possible through means of communication built into the learning management system (LMS), e-mail, messengers (Viber, Telegram, etc.), video conferencing (MS Teams, ZOOM, Google Meet, Skype, etc.),

${ }^{23}$ Про захист населення від інфекційних хвороб: Закон України від 06.04.2000 p. № 1645-III. Дата оновлення: 23.05.2020. URL: https://zakon.rada.gov.ua/ laws /show /1645-14.

${ }^{24}$ Про запобігання поширенню на території України гострої респіраторної хвороби COVID-19, спричиненої коронавірусом SARS-CoV-2: Постанова Кабінету Міністрів України від 11.03.2020 р. № 211. URL: https://zakon.rada.gov.ua/laws/show/211-2020-\%D0\%BF.

${ }_{25}$ Про організаційні заходи для запобігання поширенню коронавірусу COVID - 19: Наказ Міністерства освіти і науки України від 16.03.2020 р. № 406. URL: file://C:/Users/User/ Downloads/5e6fac624019c419382889\%20(1).pdf. 
forums, chats, etc. In turn, control measures of the educational process with the use of distance learning technologies must meet specific requirements: 1) the possibility of authorized access to information and communication tools for distance learning; 2) the ability to determine the start and end time of access, the duration of tasks; 3 ) the objectivity of the criteria for verifying the results of performance with the active use of automated assessment tools; 4) variability of formation of tasks of control actions with use of algorithms of a random choice of questions. Regarding the current control of learning outcomes of higher education recipients with the help of distance technologies, it is carried out during distance learning, as well as by assessing individual and group tasks performed by higher education recipients in electronic form ${ }^{26}$.

In this context, it should be noted that in accordance with Art. 62 of the Law of Ukraine «On Higher Education» persons studying in higher education institutions have the right to choose the form of education when entering a higher education institution ${ }^{27}$. That is, the unauthorized change of the form of education to some extent violated this right, which requires a separate scientific study.

First of all, distance learning was interpreted by Article 49 of the Law of Ukraine «On Higher Education» as an analogue of distance learning, but this rule has expired ${ }^{28}$. According to the Law of Ukraine «On Higher Education», distance learning is referred to the institutional form of education at the level of full-time, part-time and network forms ${ }^{29}$. A more complete definition of distance learning is contained in the current Regulation on distance learning, which is enshrined in the order of the Ministry of Education and Science of Ukraine. Accordingly, distance learning is an individualized process of acquiring knowledge, skills, abilities and ways of human cognitive activity, which occurs through the interaction of distant participants in the learning process in a specialized environment and operates on the basis of modern psychological, pedagogical and information and communication

\footnotetext{
${ }^{26}$ Рекомендації щодо організації поточного, семестрового контролю та атестації здобувачів вищої освіти із застосуванням дистанційних технологій: Лист Міністерства освіти і науки України від 14 травня 2020 р. № 1-9. 249. URL: https://mon.gov.ua/ua/npa/ shodo-organizaciyi-potochnogo-semestrovogo-kontrolyu-ta-atestaciyi-zdobuvachiv-osviti-izzastosuvannyam-distancijnih-tehnologij.

27 Про вищу освіту: Закон України від 01.07.2014 № 1556-VII. Дата оновлення: 21.06.2020 p. URL: https://zakon.rada.gov.ua/laws/show/1556-18\#Text.

${ }_{28}$ Про вищу освіту: Закон України від 01.07.2014 № 1556-VII. Офіиійиний вісник Украӥни. 2014. № 63. Ст. 7 (редакція втратила чинність).

29 Про вищу освіту: Закон України від 01.07.2014 p. № 1556-VII. Дата оновлення: 21.06.2020 p. URL: https://zakon.rada.gov.ua/laws/show/1556-18\#Text.
} 
technologies. In this case, distance learning is implemented by: a) the use of distance learning as a separate form of learning; b) the use of distance learning technologies to provide learning in various forms ${ }^{30}$.

Distance learning mediates the specifics of training sessions, namely: 1) receiving training materials, communication between subjects of distance learning during training sessions is provided by transmitting video, audio, graphic and textual information in synchronous or asynchronous mode; 2) practical training, which involves the implementation of practical (control) work remotely in asynchronous mode (some practical tasks can be performed in synchronous mode, as determined by the working program of the discipline); 3) laboratory classes are conducted in person in specially equipped training laboratories or remotely using the appropriate virtual simulators and laboratories; 4) other types of training sessions in the implementation of the educational process may include: business games, project implementation in groups, etc.; 5) practical training of recipients of higher education who study at a distance form of education is carried out according to a separately approved program by the educational institution.

To meet the established regulatory requirements, it is advisable to create a national Council of Ukraine for Distance Education under the Ministry of Education and Science of Ukraine, the main task of which will be institutional and legal support for the introduction of various forms of distance learning in higher education, taking into account globalization and humanization; elaboration of a simplified procedure for licensing distance forms of education in higher educational institutions; development of a single concept of creating a network of open universities in Ukraine, which carry out educational activities in various specializations, etc.

The introduction of distance learning, before the introduction of restrictive measures, was considered exclusively within the concept of informatization of education through a set of interconnected organizational, legal, political, socio-economic, scientific and technical, production processes aimed at creating conditions to meet the information needs of citizens and society based on the creation, development and use of information systems, networks, resources and information technologies, which are built on the use of modern computer and communication technology ${ }^{31}$. From now on, the informatization of higher education, having acquired a new justification,

\footnotetext{
${ }^{30}$ Про дистанційне навчання: Наказ МОН України від 25.04.2013 № 466. Офіційний вісник України. 2013. № 36. Ст. 202.

31 Про Національну програму інформатизації: Закон України від 04.02.1998 № 74/98BP. Дата оновлення: 07.06 .2020 p. URL: https://zakon.rada.gov.ua/laws/show/74/98$\%$ D0\%B2\%D1\%80\#Text.
} 
should become the leading direction of development of science and education in Ukraine.

The National Strategy for Education Development in Ukraine for the period up to 2021 states that the priority of education development is the introduction of modern information and communication technologies that improve the educational process, accessibility and effectiveness of education, preparing the younger generation for life in the information society. The measures aimed at fulfilling the task in the field of higher education and relating to the development of distance learning in Ukraine include:

- formation and implementation of information educational environment in the system of higher and postgraduate education, application in the educational process and library work along with traditional means of information and communication technologies;

- development of individual modular training programs of different levels of complexity depending on specific needs;

- creation of an information system to support the educational process, aimed at carrying out its main functions (training, socialization, internal control over the implementation of educational standards, etc.);

- full provision of vocational and technical, higher educational institutions with educational computer complexes, as well as basic educational institutions of educational districts with multimedia equipment;

- creation of electronic textbooks and encyclopedias for educational purposes;

- creation of a distance learning system, including for people with special educational needs;

- providing the educational process by means of information and communication technologies, as well as access of educational institutions to world information resources;

- creation of a system of information and analytical support in the field of management of educational institutions, information and technological support for monitoring education, etc ${ }^{32}$.

In addition, the introduction of distance learning in the educational process is mediated by the tasks facing the institution of higher education, such as providing an organic combination in the educational process of educational, scientific and innovative activities; creation of necessary conditions for realization by participants of educational process of their

32 Про Національну стратегію розвитку освіти в Україні на період до 2021 року: Указ Президента України від 25 червня 2013 року № 344/2013. URL: https://zakon.rada.gov.ua/laws/ show/344/2013\#Text. 
abilities and talents; dissemination of knowledge among the population, raising the educational and cultural level of citizens; establishing international relations and conducting international activities in the field of education, science, sports, arts and culture.

\section{CONCLUSIONS}

This study developed a list of issues that identified the main requirements that determine the feasibility of analysis and use of distance learning technologies: a) a systematic understanding of the essence of distance learning and its didactic features; b) definition of the basic categories of distance learning technologies. The basic normative and legal grounds of distance learning in Ukraine before the introduction of restrictive and quarantine measures to counteract the spread of the COVID - 19 pandemic and during their operation have been established.

The normative requirements to the control measures of the educational process with the use of distance technologies are singled out: 1) the possibility of authorized access to information and communication tools for the organization of distance learning; 2) the ability to determine the start and end time of access, the duration of tasks; 3 ) the objectivity of the criteria for verifying the results of performance with the active use of automated assessment tools; 4) variability of formation of tasks of control actions with use of algorithms of a random choice of questions.

Attention is drawn to the shortcomings of public administration in the field of higher education regarding the use of distance learning, namely: the lack of a modern concept of distance education; lack of regulatory and institutional support for the functioning of distance learning; the lack of a single mechanism for adjusted coordination of higher education institutions and agencies in the framework of experimental work on the development and creation of a system of distance education in Ukraine; lack of expert assessment of the quality of distance learning organization and means of educational and methodological support; inadequate level of training in the field of distance education: tutors, teachers, administrators, course developers, etc.

\section{SUMMARY}

The article is devoted to the study of theoretical and legal bases of changing the vector of public administration in the field of higher education to distance learning. The process of distance learning is defined as the transfer of information of a certain content (knowledge, skills, abilities), the ultimate goal of which is the ability of the higher education recipients 
to use this information in their activities. The main characteristics of the process of information transfer within distance learning include: 1) the main cognitive process through which the process of transmission, assimilation and application of information by the higher education recipient; 2) the level and nature of feedback from the higher education recipient in the learning process, as well as the degree of adaptation of the learning process to the individual characteristics of the higher education recipient: psychological structure of personality, sociological structure of personality, level of learning and ability to learn; management style of the learning process, which is based on the principled recognition or non-recognition of the fact of individuality of the student's personality and can be authoritarian or humanistic.

It is proposed to establish a national Council of Ukraine for Distance Education under the Ministry of Education and Science of Ukraine, the main task of which will be institutional and legal support for the introduction of various forms of distance learning in higher education, taking into account globalization and humanization; elaboration of a simplified procedure for licensing distance forms of education in higher educational institutions; development of a single concept of creating a network of open universities in Ukraine, which carry out educational activities in various specializations, etc.

\section{REFERENCES}

1. Kose U., Koc D. Artificial Intelligence Applications in Distance Education. IGI Global, 2014. 357 p.

2. Negash S., Whitman Michael E., Woszczynski Amy B.. Handbook of Distance Learning for Real-Time and Asynchronous Information Technology Education. New York: Hershey, 2008. 381 p.

3. Sergey Kivalov, Liubov Bila-Tiunova (2020) Motivational values of Ukrainian students and the use of distance learning form in legal education. Universal journal of educational research. Vol. 8. No. 2. P. 260-283.

4. Биков В.Ю., Кухаренко В.М. Технологія розробки дистанційного курсу. Київ : Міленіум, 2008. 324 с.

5. Боцула М.П., Кречман Д.Л., Плахотник I.B. ELearning Server. Рекомендації тьюторам. Методичний посібник. 2-е вид. Вінниця : ВНТУ, 2015. $158 \mathrm{c}$

6. Годжаев Р.С. Применение современных технологий в образовательном процессе. Краснодар : Місль, 2012. 196 с.

7. Гусак Т., Малінко О. Можливості та перспективи дистанційного навчання у вузі. Рідна школа. 2000. № 10. С. 41-42.

8. Демкин В.П., Можаева Г.В. Технологии дистанционного обучения. Монография. Томск : Изд-во Том. ун-та, 2013. 106 с. 
9. Дотримання демократії, верховенства права та прав людини під час санітарної кризи, спричиненої COVID-19. Інформаційні документи. Рада Свропи. 7 April 2020 SG/Inf(2020)11. URL : https://www.coe.int/en/ web /congress/covid-19-toolkits.

10. Кашицин В.П. Дистанционное обучение в высшей школе: модели и технологии. 3-е изд. доп. Москва : Центр информатизации Минобразования России, 2009. 42 с.

11. Конституція України. Із змінами, внесеними Законом України від 08.12.2004 p. № 2222-IV. Дата оновлення 01.01.2020 p. URL : http://zakon2.rada.gov.ua/laws/show/254\%D0\%BA/96-\%D0\%B2\%D1\%80.

12. Концепція розвитку дистанційної освіти в Україні: Постанова Міністерства освіти та науки України від 20 грудня 2000 р. Міністерства освіти і науки України від 20 грудня 2000 p. URL : http:/www.osvita.org.ua/ distance/pravo/00.html.

13. Корсунська Н.О. Дистанційне навчання: підходи до реалізації. Сучасні інформаційні технології та інноваційні методики навчання в підготовиі фахівиів: методологія, теорія, досвід, проблеми: Зб. наук. праць. Київ-Вінниця : ДОВ Вінниця, 2000. С. 29-32.

14. Кухаренко В.М. Дистанційне навчання. Харків : ХДПУ, 1999. 216 с.

15. Молчина Л.И., Сидорик В.В., Стрелкова И.Б. Технология разработки электронных учебно-методических комплексов / Под общ. ред. В.В. Сидорика, Л.И. Молчиной. Минск : БНТУ, 2015. 263 с.

16. Про вищу освіту : Закон України від 01.07.2014 р. № 1556-VII. Дата оновлення:21.06.2020p.URL:https://zakon.rada.gov.ua/laws/show/1556-18\#Text.

17. Про вищу освіту : Закон України від 01.07.2014 № 1556-VII. Офіџійний вісник України. 2014. № 63. Ст. 7 (редакиія втратила чинність).

18. Про дистанційне навчання : Наказ $\mathrm{MOH}$ України від 25.04.2013 № 466. Офіиійний вісник України. 2013. № 36. Ст. 202.

19. Про запобігання поширенню на території України гострої респіраторної хвороби COVID-19, спричиненої коронавірусом SARSCoV-2: Постанова Кабінету Міністрів України від 11.03.2020 р. № 211. URL : https://zakon.rada.gov.ua/laws/show/211-2020-\%D0\%BF.

20. Про захист населення від інфекційних хвороб : Закон України від 06.04.2000 р. № 1645-III. Дата оновлення: 23.05.2020. URL : https://zakon.rada.gov.ua/ laws /show /1645-14.

21. Про Національну програму інформатизації : Закон України від 04.02.1998 № 74/98-BP. Дата оновлення: 07.06.2020 p. URL : https://zakon.rada.gov.ua/laws/show/74/98-\%D0\%B2\%D1\%80\#Text.

22. Про Національну стратегію розвитку освіти в Україні на період до 2021 року : Указ Президента України від 25 червня 2013 року № 344/2013. URL : https://zakon.rada.gov.ua/laws/show/344/2013\#Text. 
23. Про організаційні заходи для запобігання поширенню коронавірусу COVID - 19 : Наказ Міністерства освіти і науки України від 16.03.2020 p. № 406. URL : file://C:/Users/User/Downloads/5e6fac624019c419382889\%20 (1).pdf.

24. Про освіту: Закон України від 05.09.2017 p. № 2145-VIII. Дата оновлення: 24.06 .2020 p. URL : https://zakon.rada.gov.ua/laws/ show/2145-19\#Text.

25. Рекомендації щодо організації поточного, семестрового контролю та атестації здобувачів вищої освіти із застосуванням дистанційних технологій: Лист Міністерства освіти і науки України від 14 травня 2020 p. № 1-9. C. 249. URL : https://mon.gov.ua/ua/npa/shodoorganizaciyi-potochnogo-semestrovogo-kontrolyu-ta-atestaciyi-zdobuvachivosviti-iz-zastosuvannyam-distancijnih-tehnol ogij.

26. Шамахов В.А., Суслов Ю.Е., Золотухин В.А. Современное дистанционное образование государственных служащих: проблемы и решения. Санкт-Петерубрг : Астерион, 2013. 184 с.

\section{Information about authors:} Bilous-Osin T. I., $\mathrm{PhD}$ in Law, Associate Professor at the Department of Administrative and Financial Law National University "Odesa Law Academy" 23, Fontanska doroha str., Odesa, 65009, Ukraine

Kozachuk D. A., $\mathrm{PhD}$ in Law, Associate Professor at the Department of Administrative and Financial Law National University "Odesa Law Academy" 23, Fontanska doroha str., Odesa, 65009, Ukraine 